\author{
O. Dolia ${ }^{1}$, K. Dolia ${ }^{2}$ \\ ${ }^{1}$ Kharkiv National University of Radio Electronics, Ukraine \\ ${ }^{2}$ O.M. Beketov National University of Urban Economy in Kharkiv, Ukraine
}

\title{
CHANGES IN THE PARAMETERS OF FUNCTIONING OF INTERCITY PASSENGER TRANSPORTATION SYSTEM
}

The speed of communication on any route, directly and indirectly through the function of redistribution of traffic volumes, causes an increase in the number of movements, traffic volumes, transport work, in the network of the appropriate type, at the same time the values of the medium system coefficient of passenger capacity use and the number of vehicles may vary both in the direction of the increase and vice versa. The results of the calculations of the basic parameters of the functioning of intercity passenger route systems for various values of the speed of communication on intercity railway routes established the appropriate mathematical model for determining the parameters of this passenger communication.

Keywords: transport system, intercity passenger transport route, basic parameters of transportation, efficiency, model.

\section{Introduction}

The results of the work determined the basic indicators of the functioning of the system of intercity passenger traffic. These indicators include: the number of movements in the network; volume of transportation; transfer ratio; transport work; average distance of the route; average distance of the network ride; medium coefficient of passenger capacity use; required number of buses / cars. According to the analysis of the methods and models of calculations of the basic indicators of the functioning of the system of intercity passenger traffic, it was assumed that the change in the quantitative characteristics of the parameters entering into the system or the quantitative characteristics of its elements may lead to a change in the quantitative indicators of the functioning of the system itself or its individual elements. The hypothesis about the possibility of dependencies of the basic indicators of the functioning of the system of intercity passenger route transportation from the parameters of the parameters or elements of the system itself is introduced. The analysis of scientific approaches to the substantiation of the theoretical foundations of systems of intercity passenger route transportations shows that the process of functioning of certain transportations does not fully take into account the complexity of interconnections of the basic characteristics of such systems and their mutual influence. The theoretical basis for studying the basic laws of the functioning of the system of interurban passenger route transportation should be based on scientific approaches that take into account the changes in the input parameters in this system.

\section{Theoretical Background}

The study of travel behavior was mainly limited to an understanding of transport models in urban and interregional areas [1-3], such as traveling outside of your "usual residence" using public transport, namely buses.

The modal choice for long journeys depends on the various characteristics of the trip, including the purpose of the trip and the destination to which the trip is being made. Models for choosing a logistic regime for life were created for night and single trips from urban and rural areas [4-6]. In addition, the time of year was a significant factor influencing long journeys [7-9].

All passengers are divided into several classes according to certain economic characteristics [10]. There are also several ways to transport passengers to choose from. To determine the passenger's behavior when choosing a vehicle, the theory of utility, the utility function, is given in the literature [11-13]. Usually passengers choose vehicles on the basis of their ideas about the advantages of their transportation, and not about others. In accordance with the characteristics of the passenger traffic structure, an organizational structure of passenger traffic was created taking into account the cost, time, safety and comfort of the passenger in terms of the average passenger. This demonstrates the fairness of the organizational model of interregional passenger transportation [14].

The quality of passenger road transport plays a large role in the future demand of urban and interregional passenger transport [15-17]. Analysis of the best practices in the organization and management of urban passenger transport shows that the main goal of public transport is not only providing services in the required 
quantity, but also meeting the growing needs of the population in passenger services [18]. Assessment of the passenger and quality depends on various factors that are evaluated by qualitative indicators.

\section{Materials and Experiments}

Influence of speed of connection in the railway network on its parameters was provided by modeling of the operation of the railway route network of intercity passenger routes in Ukraine taking into account the distribution of routes into two groups according to the maximum speed of communication on the route. The simulations take into account the existing 25 nodes, which are determined by the regional centers, and 92 railway tracks. Among the identified railway routes are those that provide a speed of driving up to $80 \mathrm{~km} / \mathrm{h}$. and up to $160 \mathrm{~km} / \mathrm{h}$. This is due to the division of the intercity passenger route network into two networks. The first route network of rail transport includes 76 routes with speeds up to $80 \mathrm{~km} / \mathrm{h}$, another one includes 16 with speeds up to $160 \mathrm{~km} / \mathrm{h}$. The variable input parameter in the system of intercity rail passenger routes is the speed of communication on the routes of the second group. It was chosen that the speed of the first group was unchanged, and the speed of the connection on the second routes increased by $10 \%, 20 \%, 40 \%, 60 \%, 80 \%$ and $100 \%$. Based on the results of the calculations, the basic indicators of operation of the first and second railway network, which are summarized in tables 1 and 2, were determined.

Table 1

Basic indicators of functioning of the first group of railway route networks with speed of communication ( $\left.\mathrm{V}_{\text {сп.мар.мер.1 }}\right) 60 \mathrm{~km} . / \mathrm{h}$. when changing the speed of communication $\left(\mathrm{V}_{\text {сп.мар.мер.2) }}\right.$ in the second group

\begin{tabular}{|c|c|c|c|c|c|}
\hline 1,7 & 1,9 & 2,2 & 2,5 & 2,9 & 3,2 \\
\hline 39765 & 38676 & 35953 & 33228 & 30505 & 27781 \\
\hline 48105 & 46790 & 43495 & 40198 & 36904 & 33607 \\
\hline 1,21 & 1,21 & 1,21 & 1,21 & 1,21 & 1,21 \\
\hline 18214 & 17715 & 16467 & 15220 & 13973 & 12725 \\
\hline 415 & 415 & 415 & 415 & 415 & 415 \\
\hline 458 & 458 & 458 & 458 & 458 & 458 \\
\hline 0,38 & 0,38 & 0,38 & 0,38 & 0,38 & 0,38 \\
\hline 1351 & 1314 & 1222 & 1134 & 1046 & 960 \\
\hline
\end{tabular}

Table 2.

Basic indicators of functioning of the second group of railway route networks with speed of communication $\left(\mathrm{V}_{\text {сп.мар.мер.1 }}\right)$ ) $60 \mathrm{~km} . / \mathrm{h}$ when changing the speed of communication $\left(\mathrm{V}_{\text {сп.мар.мер.2) }}\right)$ in the second group.

The ratio of speeds between intercity rail networks $\mathrm{V}_{\text {сп.мар.мер.2 }} / \mathrm{V}_{\text {сп.мар.мер.1 }}$

\begin{tabular}{|l|l|l|l|l|l|}
\hline 1,7 & 1,7 & 1,7 & 1,7 & 1,7 & 1,7 \\
\hline 14708 & 15797 & 18520 & 21245 & $\begin{array}{l}2396 \\
8\end{array}$ & 26692 \\
\hline & & & & 2163 & \\
13275 & 14259 & 16716 & 19178 & 6 & 24094 \\
\hline 1,11 & 1,11 & 1,11 & 1,11 & 1,11 & 1,11 \\
\hline 8381 & 9003 & 1055 & 1210 & 1365 & 1521 \\
\hline 529 & 529 & 529 & 529 & 529 & 529 \\
\hline 570 & 570 & 570 & 570 & 570 & 570 \\
\hline 0,39 & 0,38 & 0,38 & 0,39 & 0,39 & 0,39 \\
\hline 204 & 221 & 259 & 294 & 329 & 367 \\
\hline
\end{tabular}

\section{Results}

The information given in table. provide an opportunity in building appropriate graphs of changes in pas-

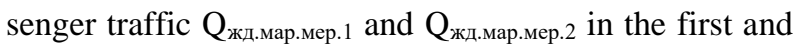
second group of intercity railway passenger routes. Fig. 1 shows the corresponding graphs.

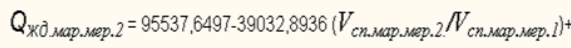

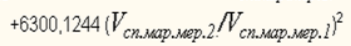

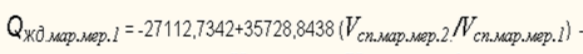

$$
\begin{aligned}
& -5766,8311\left(V_{\text {cn.wap.sep.2. }} / V_{\text {cn...ap. wep. } .1}\right)^{2}
\end{aligned}
$$

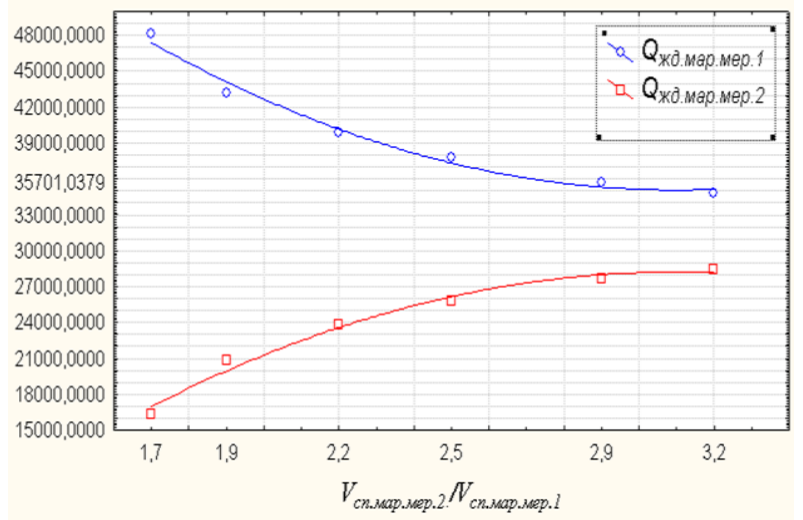

Fig. 1. Graph of changes in the parameters of passenger traffic $\mathrm{Q}_{\text {жд.мар.мер.1 }}$ and $\mathrm{Q}_{\text {жд.мар.мер.2 }}$ in the first and second groups of intercity railway passenger routes

The functions of the dependence of $\mathrm{P}_{\text {жд.мар.мер.2 } 2 \text { and }}$ $\mathrm{P}_{\text {жд.мар.мер.1 }}$ from $\mathrm{V}_{\text {сп.мар.мер.2 }} / \mathrm{V}_{\text {сп.мар.мер.1 }}$ are determined.

$Q$ (жд.мар.мер.1) - the number of passengers carried by the first group of railway routes. 


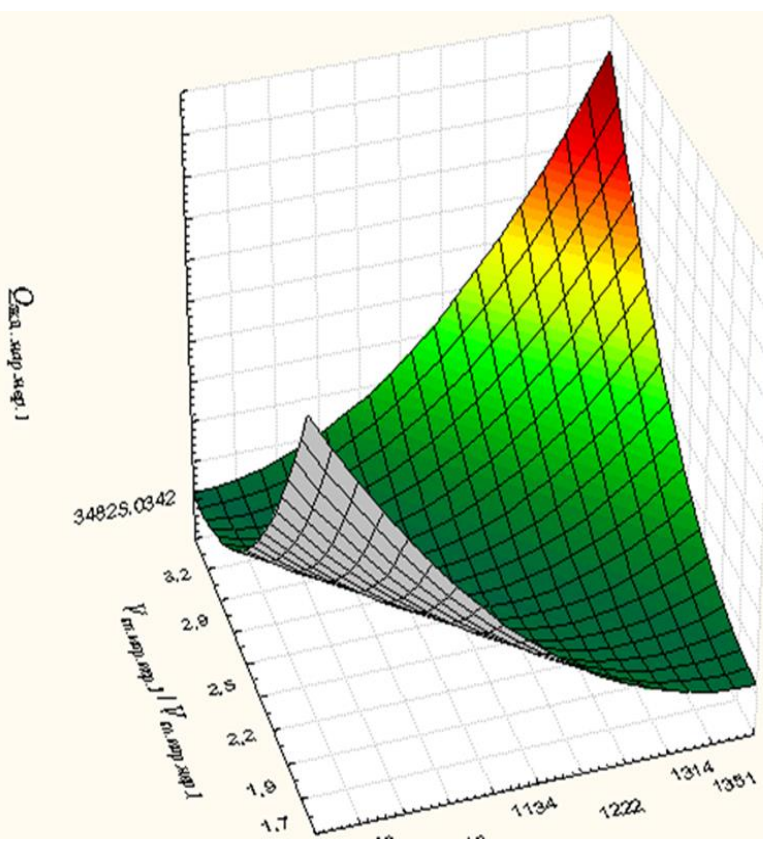

Fig. 2. Graph of dependency $\mathrm{Q}_{\text {жд.мар.мер.1 from }}$

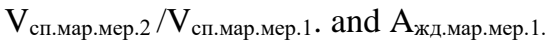

Fig. 2. shows a graph of the dependence of $Q_{\text {жд.мар.мер.1 }}$ from $V_{\text {сп.мар.мер. } 2} / V_{\text {сп.мар.мер.1. }}$ and $A_{\text {жд.мар.мер.1 }}$, where $A_{ж д \text { мар.мер.l }}$ number of vehicles.

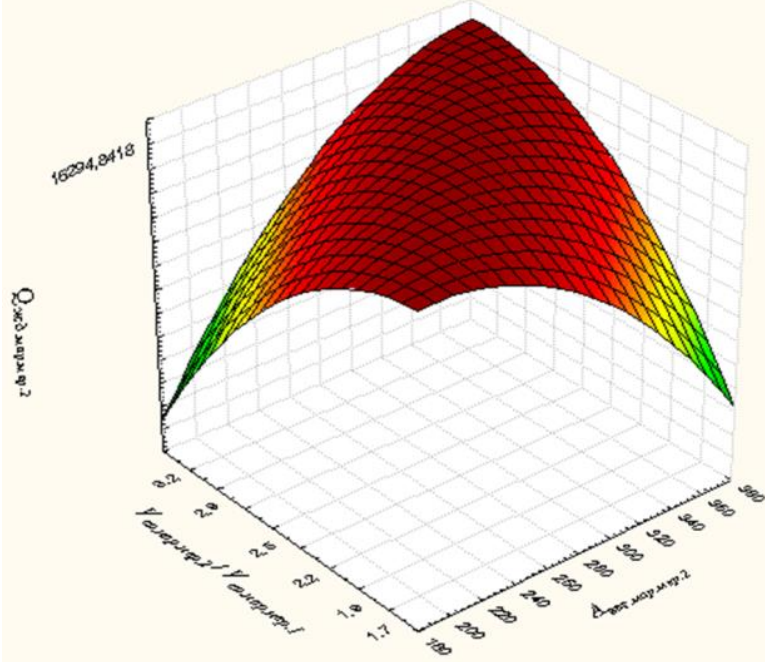

Fig. 3. Graph of dependency $\mathrm{Q}_{\text {жд.мар.мер.2 from }}$

$\mathrm{V}_{\text {сп.мар.мер.2 }} / \mathrm{V}_{\text {сп.мар.мер.1. }}$ and $\mathrm{A}_{\text {жд.мар.мер.2 }}$

Fig. 3. shows a graph of the dependence of

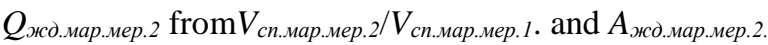

According to the obtained functions, it is possible to carry out the corresponding calculations of the values $Q_{\text {мар.мер.1 }}$ and $Q_{\text {мар.мер.2 }}$ to compare them with the tabular ones according to the table. 5.6.1. and 5.6.2, which will ensure that $\Delta Q_{\text {мар.мер.1 }}$ and $\Delta Q_{\text {мар.мер.2 }}$ are calculated between these indicators. The results are summarized in Table 3.
Table 3.

Comparison of tabular and calculated values of

\begin{tabular}{|c|c|c|c|c|c|}
\hline \multicolumn{6}{|c|}{$\mathrm{P}_{\text {мар.мер.1 }}$ and $\mathrm{P}_{\text {мар.мер.2 }}$} \\
\hline \multicolumn{2}{|c|}{ Tabular values } & \multicolumn{2}{|c|}{ Calculated values } & \multirow{2}{*}{$\Delta Q_{\text {nap. }}$} & \multirow{2}{*}{$\Delta Q_{\text {мар.ме }}$} \\
\hline $\begin{array}{l}Q_{\text {мар.мер. }} \\
l\end{array}$ & $\begin{array}{l}Q_{\text {мар.мер. }} . \\
2\end{array}$ & $\begin{array}{l}Q_{\text {мар.мер. }} . \\
1\end{array}$ & $\begin{array}{l}Q_{\text {мар.мер. }} . \\
2\end{array}$ & & \\
\hline 48115 & 16294 & 51965 & 17598 & $5,79 \%$ & $8 \%$ \\
\hline 43167 & 20823 & 45758 & 21865 & $3,13 \%$ & $5 \%$ \\
\hline 39873 & 23841 & 45854 & 27180 & $5,97 \%$ & $14 \%$ \\
\hline 37785 & 25749 & 39297 & 23818 & $9,22 \%$ & $-8 \%$ \\
\hline 35701 & 27658 & 42127 & 30148 & $10,90 \%$ & $9 \%$ \\
\hline 35870 & 28461 & 35870 & 31592 & $10,22 \%$ & $11 \%$ \\
\hline Total: & & & & $9 \%$ & $9,08 \%$ \\
\hline
\end{tabular}

\section{Література}

1. Dolya K.V. Gravity Model Formalization for Parameter Calculation of Intercity Passenger Transport Correspondence / K. Dolya // SCIENCE \& TECHNIQUE. - 2017. - T. 16, № 5. -P. 437-443.

2. Dolya C. Вплив особливостей малюнку транспортної мережі на довжину їзки між ії вузлами на прикладі транспортної мережі Украӥни [Електронний ресурс] / Konstantine Dolya, Sergey Lyfenko, Sergey Nesterenko, Konstantin Vyatkin // Технологічний аудит та резерви виробництва. - 2017. - T. 5, N 2(37). - C. 54-58. - DOI : $10.15587 / 2312-8372.2017 .112078$

3. Dolia K. Variativity of the Transport System at Intercity Passenger Transport from the Demand [Електронний реcypc] / K. Dolya // International Journal of Data Science and Analysis. - 2017. - T. 3, №. 6. - P. 77-84. - DOI : 10.11648/j.ijdsa.20170306.13

4. Dolya C. Вплив особливостей малюнку транспортноі мережі на довжину їздк між ії вузлами на прикладі транспортної мережі України [Електронний ресурс] / Konstantine Dolya, Sergey Lyfenko, Sergey Nesterenko, Konstantin Vyatkin // Технологічний аудит та резерви виробництва. - 2017. - T. 5, N 2(37). - C. 54-58. - DOI : $10.15587 / 2312-8372.2017 .112078$

5. Dolya, C. Modeling of intercity passenger transportation system / Constantine Dolya // Technology audit and production reserves. - 2017. - Vol. 2, N 2(34). - P. 37-43. DOI : $10.15587 / 2312-8372.2017 .100465$

6. Dolya K. Моделювання пасажирських транспортних кореспонденцій між обласними центрами в Украйні [Електронний ресурс] / K. Dolya // Технологічний аудит ma резерви виробництва. - 2017. - T. 1, N 2(33). - C. 44-48. DOI : $10.15587 / 2312$ - 8372.2017.93458.

7. Galkin A. The Role of Consumers in Logistics Systems [Electronic resource] / Galkin A., Dolia K., Davidich N. // Transportation Research Procedia. - 2017. - No. 27. P. 1187-1194. DOI: 10.1016/j.trpro.2017.12.010

8. Dolya K. Management of Freight Transport Projects in Cities in Assessing Their Effectiveness / K. Dolya, A. Botsman, O. Dolia, S. Lyfenko // Software Engineering. - 2016. - Vol. 6, No. 2. - P. 63-68. DOI: 10.11648/j.se.20180602.15

9. Galkin A. Influencing financial flows on logistics technology solutions (case study on transportation modeselection) / Galkin A., Dolya K. // Prace Naukowe Politechniki Warszawskiej. Transport. - 2017. -Vol. 117. P. 61-73. 


\section{References}

1. Dolya, C.V. (2017). Gravity Model Formalization for Parameter Calculation of Intercity Passenger Transport Correspondence. SCIENCE \& TECHNIQUE, 16(5), 437-443. 2. Dolia, K., Davidich, Y., Dolia, O., Lyfenko, S., \& Uhodnikova, O. (2017). Modeling of polygons of maximum passenger route transport accessibility by the example of the transport system of Ukraine. Technology audit and production reserves, $6(2(38)), 28-33$.

3. Kostiantyn, D. (2017). Variativity of the Transport System at Intercity Passenger Transport from the Demand. International Journal of Data Science and Analysis, 3(6), 77. 4. Dolya, C., Lyfenko, S., Nesterenko, S., \& Vyatkin, K. (2017). Influence of features of the transport network pattern on the haul cycle length between its nodes on the example of the transport network of Ukraine. Technology audit and production reserves, 5(2 (37)), 54-58.

5. Dolya, C. (2017). Modeling of intercity passenger transportation system. Technology audit and production reserves, (2 (2)), 37-43.

6. Dolya, C. (2017). Modeling of passenger transport correspondence between regional centers in Ukraine. Technology audit and production reserves, 1(2 (33)), 44-48.

7. Galkin, A., Dolia, C., \& Davidich, N. (2017). The Role of Consumers in Logistics Systems. Transportation Research Procedia, 27, 1187-1194.

8. Kostiantyn, D., Olena, D., Sergey, L., \& Anastasiia, B. (2018). Management of Freight Transport Projects in Cities in Assessing Their Effectiveness. Software Engineering, 6(2), 63.
9. Galkin, A., \& Dolya, C. (2017). Influencing financial flows on logistics technology solutions (case study on transportation mode selection). Prace Naukowe Politechniki Warszawskiej. Transport.

Рецензент: доктор економічних наук, професор К.А. Мамонов, Харківський національний університет міського господарства імені О.М. Бекетова, Україна.

\author{
Автор: ДОЛЯ Олена Свгенівна \\ к.т.н., дочент кафедри інформачійних управляючих \\ систем, \\ Харківський національний університет радіоелект- \\ роніки \\ E-mail-olena.dolya@ukr.net \\ ID ORCID: https://orcid.org/0000-0002-0364-988X
}

Автор: ДОЛЯ Костянтин Вікторович

к.т.н., доцент кафедри земельного адміністрування та геоінформаційних систем

Харківський національний університет міського господарства імені О. М. Бекетова

E-mail-c.dolya@ukr.net

ID ORCID: http://orcid.org/0000-0002-4693-9158

\section{ІМІТАЦЙНЕ МОДЕЛЮВАННЯ ПАРАМЕТРІВ ФУНКЦІОНУВАННЯ ЗАЛІЗНИЧНИХ ПРОСКТІВ} О.С. Доля ${ }^{1}$, К.В. Доля ${ }^{1}$

${ }^{1}$ Харківський національний університет радіоелектроніки, Україна

${ }^{2}$ Харківський національний університет міського господарства імені О.М. Бекетова, Україна

Швидкість сполучення на будь-якому маршруті, прямо або побічно через функиію перерозподілу обсягів перевезень, викликає збільшення кількості перевезень, обсягів перевезень, транспортних операцій в мережі відповідного типу, при иьому середнс навантаження системи з пасажиромісткістю і кількістю транспортних засобів може змінюватися, $i$ навпаки. На основі результатів розрахунків основних параметрів систем пасажирських маршрутів далекого прямування при різних значеннях швидкості сполучення на залізничних маршрутах далекого прямування була створена відповідна математична модель для визначення параметрів даного пасажирського обслуговування. Питання розрахунку експлуатаційних характеристик транспортних засобів у міжміських пасажирських перевезеннях розглядалося багатьма вченими і є предметом досліджень донині. Основними напрямками досліджень з'явилися виявлення закономірностей зміни такого показника експлуатації транспортних засобів у далеких пасажирських перевезеннях, як обсяг пасажирських перевезень. Досліджено питання щзодо впливу факторів зовнішнього середовища на роботу транспортних засобів у міжміських пасажирських перевезеннях. Необхідно окремо визначити наукові дослідження, спрямовані на вивчення впливу змін кількісних характеристик експлуатації транспортних засобів при пасажирських міжміських перевезеннях на кількісні значення інших. Запропоновано підхід, який дозволяє моделювати попит на поӥздки та його розподіл відповідно до сочіально-економічних особливостей регіонів які з'єднує маршрут й технічних характеристик самого маршруту. Основну увагу авторами приділено визначенню можливостей регулювання обсягів перевезень за допомогою регулювання вартості такого переміщення. Метою такого дослідження було визначити таку максимальну вартість переміщення, при якій транспортні засоби були б максимально заповнено пасажирами.

Це визначає вплив зовнішнього середовища на ряд експлуатаційних параметрів иџих систем за рахунок можливості кількісної зміни параметрів, що входять в систему. Встановлено, що сучасний стан наукових підходів не повною мірою враховує взаємозв'язок між елементами системи пасажирських маршрутів далекого прямування при розрахунку основних параметрів системи. Доведено, щзо питання подальшого розвитку наукових підходів до особливостей врахування взаємного впливу кількісних характеристик елементів системи міжміських пасажирських маршрутних перевезень $\epsilon$ актуальними та такими, щзо підлягають вивченню.

Ключові слова: транспортна система, міжміський пасажирський транспортний маршрут, основні параметри перевезень, ефективність, модель.

\section{ACKNOWLEDGMENT}

This article has received

support of the project of University Nursing Program for Young Scholars with Creative Talents in Heilongjiang Province (No.UNPYSCT-2016099) 